How to cite: Bătinaş, R., Sanislai, D., Revai, A., Rafan, S. (2021) Statistical Approach on Floods Features Based on Long Term Data Series Analysis. 2021 "Air and Water - Components of the Environment" Conference Proceedings, Cluj-Napoca, Romania, p. 1-8, DOI: 10.24193/AWC2021_01.

\title{
STATISTICAL APPROACH ON FLOODS FEATURES BASED ON LONG TERM DATA SERIES ANALYSIS
}

\author{
Răzvan BĂTINAŞ ${ }^{1}$, Daniel SANISLAI ${ }^{2}$, Attila REVAI ${ }^{3}$, Sebastian RAFAN \\ DOI: 10.24193/AWC2021_01
}

\begin{abstract}
The study is focused on the assessment of basic flood features using Cavis software for raw data, recorded for a period of 40 years, between 1979 and 2019, at Satu Mare hydrometric station on the Someș River. Using the long term recorded data for the two of the largest floods in each year, we have made a statistical analysis on certain features associated with temporal frequency (monthly and seasonal occurrence), total duration, multi-daily vulnerability, maximum discharge values (in respect with the defense levels at the hydrometric station) and the total volumes of water translated through the river bed during those major flooding events.
\end{abstract}

Keywords: floods, temporal frequency, maximum discharge values, vulnerability.

\section{INTRODUCTION}

Most common natural hazards that are occurring in the north-western part of Romania are floods.

The last century of the second millennia was characterized by many episodes, most of them well studied, with the development of the national surface water management system.

The most significant ones, on the national scale, were those recorded in 1970 and 1975, with important structural damages and losses of life (Mustățea, A., 2005).

Other important events have marked especially the Apuseni mountain region analyzed by Arghiuș, 2008, Bătinaș et all, 2012, or the inner arch of the Eastern Carpathians (Maramureș area), Bătinaș et all, 2014, Șerban et all, 2020.

Another area which was affected by some important flood events is on Timiș and Bega Plain,, with large scale damages in 2005 (Chendeș et all, 2015) .

\footnotetext{
"Babeş-Bolyai" University, Faculty of Geography, Cluj-Napoca, e-mail: razvan.batinas@ubbcluj.ro

"Vasile Goldiș" University, Baia Mare, Romania, e-mail: sanislaidaniel@yahoo.com

3 "Romanian Waters" National Administration, Satu Mare, e-mail: attila.revai@sgasm.dast.rowater.ro sebastian.rafan@sgasm.dast.rowater.ro
} 
The study area is focused on the Someș River, largest watercourse in the northwestern part of Romania, with a streams network developed over a $15,881 \mathrm{~km}^{2}$ catchment area (Fig. 1).

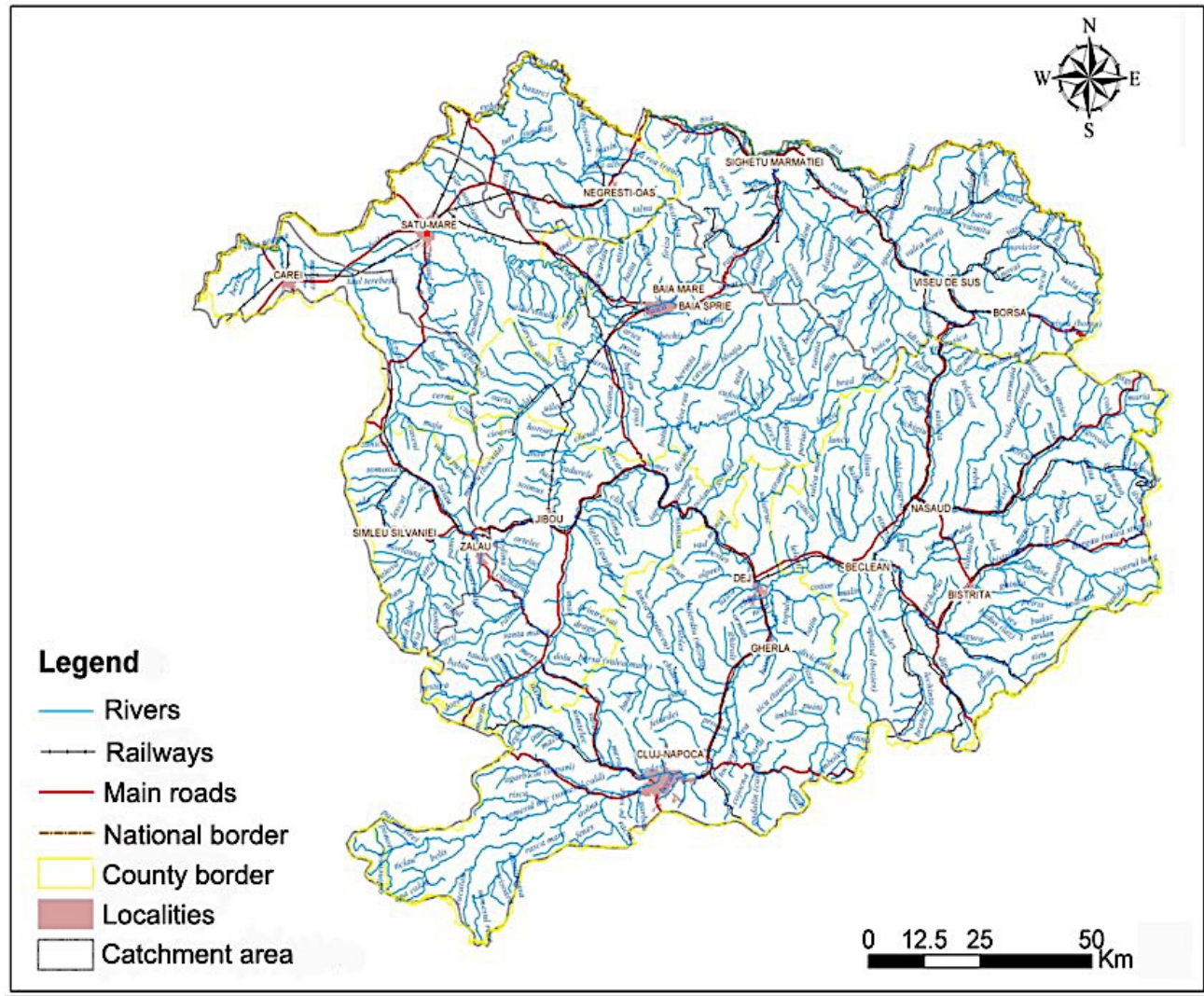

Fig. 1. Someș River catchment area within Romania.

Most of this area is situated in the Romanian territory $(98 \%$ of while the remaining $2 \%\left(306 \mathrm{~km}^{2}\right)$ lying within the borders of Hungary.

Its watershed goes along the ridges of Apuseni, Gutâi, Țibleș, Rodna, Bârgău and Călimani Mountains. Someș River takes shape by the confluence of Someșul Mare and Someșul Mic in the vicinity of Dej town.

The former has a larger catchment area and higher discharge $\left(\mathrm{Q}_{0}=47.2 \mathrm{~m}^{3} / \mathrm{s}\right)$, while the latter is longer but has a lower discharge $\left(\mathrm{Q}_{0}=21.4 \mathrm{~m}^{3} / \mathrm{s}\right)$.

The hydrometric station from Satu Mare is one of the oldest one in Romania and it's the last section who records the flow regime of Someș River within national borders (Fig. 1). 


\section{DATA AND METHODS}

In order to evaluate our statistical indicators, we have made an analysis for a 41 years period since 1979 to 2019 .

For each year has been taken into account the first two largest floods events that have occurred. Thus, we have considered 81 flood events (in 2014 was recorded only one flood), for which we have made a temporal and a data analysis.

Raw data was represented by a double data series (recorded time of observation and discharge value) and were provided by RWNA, Someș-Tisa Branch, Satu Mare Hydrological Station.

For determining basic flood features of singular floods, we used the Cavis Software developed by researchers in the National Hydrology and Water Management Institute. This application is described by two main modules: input data management and determination of singular flood wave features.

\section{RESULTS AND DISCUSSIONS}

The temporal frequency of floods was made on a seasonal and monthly base. The raw data has events that have begun in one month and have ended in the next one. For avoiding overlapping data, we have considered as a reference moment for temporal frequency the month when the flood has begun.

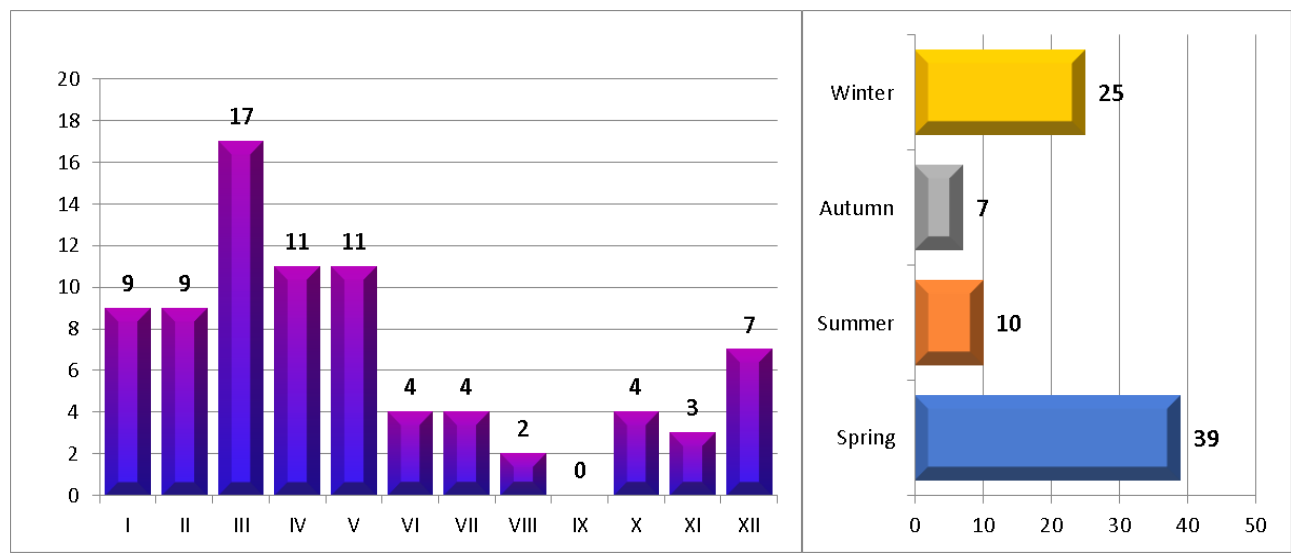

Fig. 2. The monthly and seasonal distribution of flood events at Satu Mare hydrometric station (1979 - 2019) 
The obtained results have confirmed that Spring is the season with the highest flow. From the 81 studied almost half of them ( $48 \%$ ) have occurred in this season. Summer has recorded 10 cases, while Autumn was marked by only 7 events (Fig. 2).

On the other hand, Winter, which usually is a "quiet" season hydrologically speaking has recorded a considerable number of events. This is determined by frequent intervals of time with high temperatures in the ordinary winter season, mixed with rains that are sometimes quite important as volumes.

Lately, we have noticed in the last decades an increase of Winter flood events number, for the whole country not only for the western part.

Monthly data shows that March is the month with most frequent occurrence of flood events (17), followed by the other two months on Spring, each one with 11 events. In September was not recorded any flood on the provided data series.

For a multi-yearly overview regarding the daily vulnerability, we have compiled a calendar where we overlap each flood, marking with a color its duration (Fig. 3).

After processing all data, we have observed that the most vulnerable time is the second decade of March, when in each day were counted at least 14 floods.

The most exposed day was 12 of March, day where 18 floods were recorded in the analyzed period the first half of the year (January to June) has recorded in each day at least one event.

\begin{tabular}{|c|c|c|c|c|c|c|c|c|c|c|c|c|c|c|c|c|c|c|c|c|c|c|c|c|c|c|c|c|c|c|}
\hline lanu & 1 & & 3 & 4 & 5 & 6 & 7 & 8 & 9 & 10 & 11 & 12 & 13 & 14 & 15 & 16 & 17 & $18:$ & 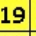 & 20 & 21 & 222 & \begin{tabular}{l|l}
23 & 24 \\
\end{tabular} & \begin{tabular}{l|l}
44 & 25 \\
\end{tabular} & 526 & 27 & 282 & 293 & \begin{tabular}{|l|l|}
30 & 3 \\
\end{tabular} & \\
\hline & 1 & & & & & & & & $y$ & & 11 & & 3 & & 5 & 16 & 17 & 18 & & 0 & 21 & & \begin{tabular}{l|l}
23 & 24 \\
\end{tabular} & 4 & 526 & 27 & 28 & & & \\
\hline & 1 & & 3 & & & & & & 9 & & 11 & & 13 & 14 & 15 & 16 & 17 & 18 & & 20 & 21 & 22 & $23 \quad 26$ & $\begin{array}{l}425 \\
\end{array}$ & 5 & 27 & 282 & 293 & $\begin{array}{ll}30 & 3 \\
\end{array}$ & \\
\hline & 1 & & 3 & & & & & & 9 & & 1 & & 3 & 14 & 5 & 16 & 17 & 18 & & 20 & 21 & & 2324 & \begin{tabular}{l|l}
44 & 25 \\
\end{tabular} & 526 & 27 & & 93 & 30 & \\
\hline May & 1 & & 3 & 4 & 5 & 6 & 7 & 8 & 9 & 10 & 11 & 12 & 13 & 14 & 15 & 16 & 17 & 18 & 19 & 20 & 21 & 222 & $23 \quad 24$ & 2425 & 26 & 27 & 282 & 293 & 303 & 31 \\
\hline n & 1 & & 3 & & & 6 & 7 & & 9 & 10 & 11 & 12 & 13 & 14 & 5 & 16 & 17 & 18 & 17 & 20 & 21 & 22 & \begin{tabular}{l|l}
23 & 24 \\
\end{tabular} & $\begin{array}{l}44 \\
25 \\
\end{array}$ & & 27 & 282 & 293 & 30 & \\
\hline | & 1 & & 3 & & & 6 & 7 & & 9 & 10 & 11 & 12 & 13 & 14 & 15 & 16 & 17 & 18 & & 20 & 21 & & \begin{tabular}{l|l}
23 & 24 \\
\end{tabular} & \begin{tabular}{l|l}
44 & 25 \\
\end{tabular} & & 27 & 282 & 293 & 303 & 31 \\
\hline Aug & 1 & 2 & 3 & 4 & 5 & 6 & 7 & 8 & 9 & 10 & 11 & 12 & 13 & 14 & 15 & 16 & 17 & 18 & 19 & 20 & 21 & \begin{tabular}{l|l}
22 & 2 \\
\end{tabular} & \begin{tabular}{l|l}
23 & 24 \\
\end{tabular} & \begin{tabular}{l|l}
44 & 25 \\
\end{tabular} & \begin{tabular}{|l|l|}
526 \\
\end{tabular} & 27 & 282 & 29 & \begin{tabular}{l|l}
30 & 3 \\
\end{tabular} & 31 \\
\hline S & 1 & & 3 & & & 6 & 7 & & 9 & 10 & 11 & 12 & 13 & 14 & 15 & 16 & 17 & 18 & 19 & 20 & 21 & \begin{tabular}{l|l}
22 & 2 \\
\end{tabular} & \begin{tabular}{l|l}
23 & 24 \\
\end{tabular} & $\begin{array}{l}44 \\
24\end{array}$ & 526 & 27 & 28 & $\begin{array}{ll}29 & 3 \\
\end{array}$ & 30 & \\
\hline & 1 & 2 & 3 & & 5 & 6 & 7 & & 9 & 10 & 11 & 12 & 13 & 14 & 15 & 16 & 17 & 18 & 19 & 20 & 21 & \begin{tabular}{l|l}
22 & 2 \\
\end{tabular} & \begin{tabular}{l|l}
23 & 24 \\
\end{tabular} & \begin{tabular}{|l|l|}
44 & 25 \\
\end{tabular} & \begin{tabular}{|l|l|}
5 & 26 \\
\end{tabular} & 27 & 282 & \begin{tabular}{|l|l|}
29 & 3 \\
\end{tabular} & \begin{tabular}{l|l}
30 & 3 \\
\end{tabular} & \\
\hline November & 1 & 2 & 3 & 4 & 5 & 6 & 7 & & 9 & 10 & 11 & & 13 & 14 & 15 & 16 & 17 & 18 & & 20 & 21 & \begin{tabular}{l|l}
22 & 2 \\
\end{tabular} & \begin{tabular}{l|l}
23 & 24 \\
\end{tabular} & $\begin{array}{l}4425 \\
\end{array}$ & 526 & 27 & $\left.28\right|^{2}$ & 293 & 30 & \\
\hline ecember & 1 & & 3 & & & 6 & & & & & 11 & & & & & 16 & 17 & 18 & & & 21 & & \begin{tabular}{l|l}
23 & 24 \\
24
\end{tabular} & \begin{tabular}{l|l}
44 & 25 \\
\end{tabular} & 526 & 27 & $\left.28\right|^{2}$ & $29 \mid 3$ & $\begin{array}{lll}30 & 3 .\end{array}$ & \\
\hline
\end{tabular}

\begin{tabular}{|c|c|c|c|}
\hline \multicolumn{4}{|l|}{ Legend } \\
\hline & 1 floods & 7 floods & 13 floods \\
\hline & 2 floods & 8 floods & 14 floods \\
\hline & 3 floods & 9 floods & 15 floods \\
\hline & 4 floods & $10 \mathrm{floods}$ & 16 floods \\
\hline & 5 floods & 11 floods & 17 floods \\
\hline & 6 floods & 12 floods & 18 floods \\
\hline
\end{tabular}

Fig. 3. The daily distribution of flood events at Satu Mare hydrometric station (1979 - 2019) 
In the second half, there are significant intervals "free of floods", where the most consistent one is beginning in the middle of September and is ending at the middle of October (31 consecutive days without any event).

The duration of flooding has a quite large variability. The shortest one was recorded in 1982 (second event), which was developed for only 63 hours, while the longest episode was observed in 2006 with 779 hours (Fig. 4).

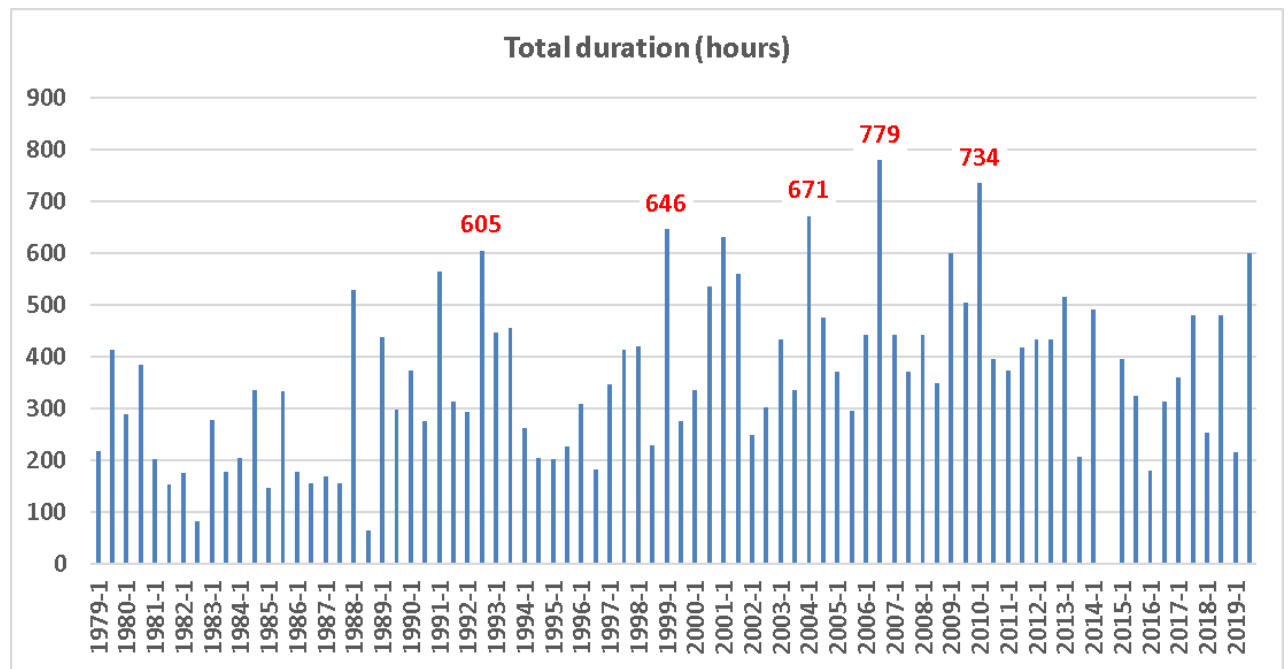

Fig. 4. The total duration of flood events at Satu Mare hydrometric station (1979 - 2019)

The average time length of a flood event at this station is around 355 hours (approx. 15 days).

The maximum discharge value recorded during the analyzed period (1979 - 2019) was about $1920 \mathrm{~m}^{3} / \mathrm{s}$, reached during the flood event from $9-17$ March 1981. If we plot all maximum discharge values on a diagram, we can observe that a certain synchronicity is revealed, leading to a 5-to-6-year time period of heavy flooding events (Fig. 5).

In the first two decades of the analyzed series the peak events are surpassing the $1000 \mathrm{~m}^{3} / \mathrm{s}$, which corresponds to the probability of occurrence of $5 \%$. The last 20 years has also highlighted a downward trend of the maxim discharge values.

The terms of water volumes which describe an ordinary flood event are the total volume, the volume form during increasing time and the volume form during decreasing phase.

In order to obtain this value, we have integrated the observed raw data into Cavis software. This program can offer wide models for obtaining the specific parameters that can describe a flood event. 


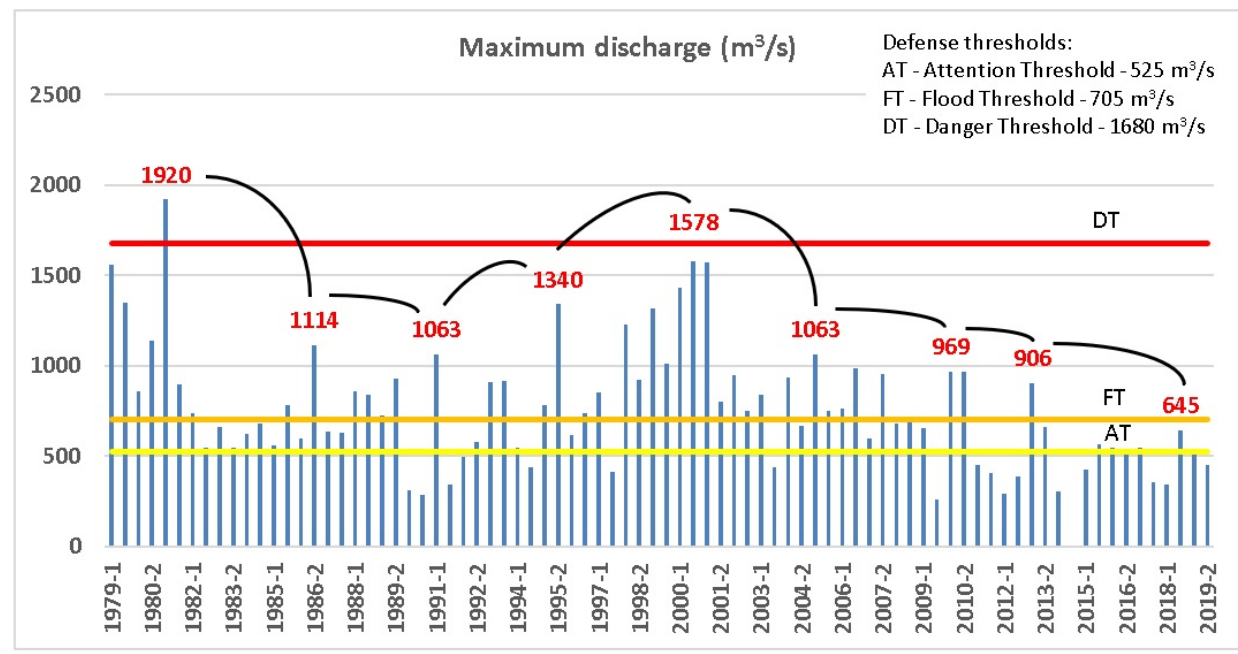

Fig. 5. The maximum discharge values observed during flood events and the 5 to 6 years cycle of major floods (1979-2019)

The largest recorded total volume was associated with the second flood of 2006, an event which has developed for around 32 days, reaching more than $1686 \mathrm{mil} . \mathrm{m}^{3}$.

Important volumes of water were transited also during the 2002 and 1999 with more than 1000 mil. $\mathrm{m}^{3}$ (Fig. 6). The average value of the total volume for the entire analyzed interval is $448 \mathrm{mil} . \mathrm{m}^{3}$.

By analyzing the 81 flood events we did manage to obtain the so-called "mean flood event" which is described by the following values: peak discharge value -764 $\mathrm{m}^{3} / \mathrm{s}$, the increasing volume $191 \mathrm{mil} . \mathrm{m}^{3}$, the decreasing volume $263 \mathrm{mil} . \mathrm{m}^{3}$, total volume of 448 mil.m $\mathrm{m}^{3}$, increasing time 133 hours, decreasing time 225 hours and total time of 355 hours.

\section{CONCLUSIONS}

Floods are one of the most frequent natural hazards that occur in Romania, and probably one that creates the largest damages, after earthquakes.

Unfortunately, these hydrological phenomena's have gained a certain pattern expressed by a temporal cycle, with a low value of occurrence.

The impact of these hazards has been considerably lowered due to the large embankment works that have been achieved in the Satu Mare city area, after the flooding events from 1970s. 


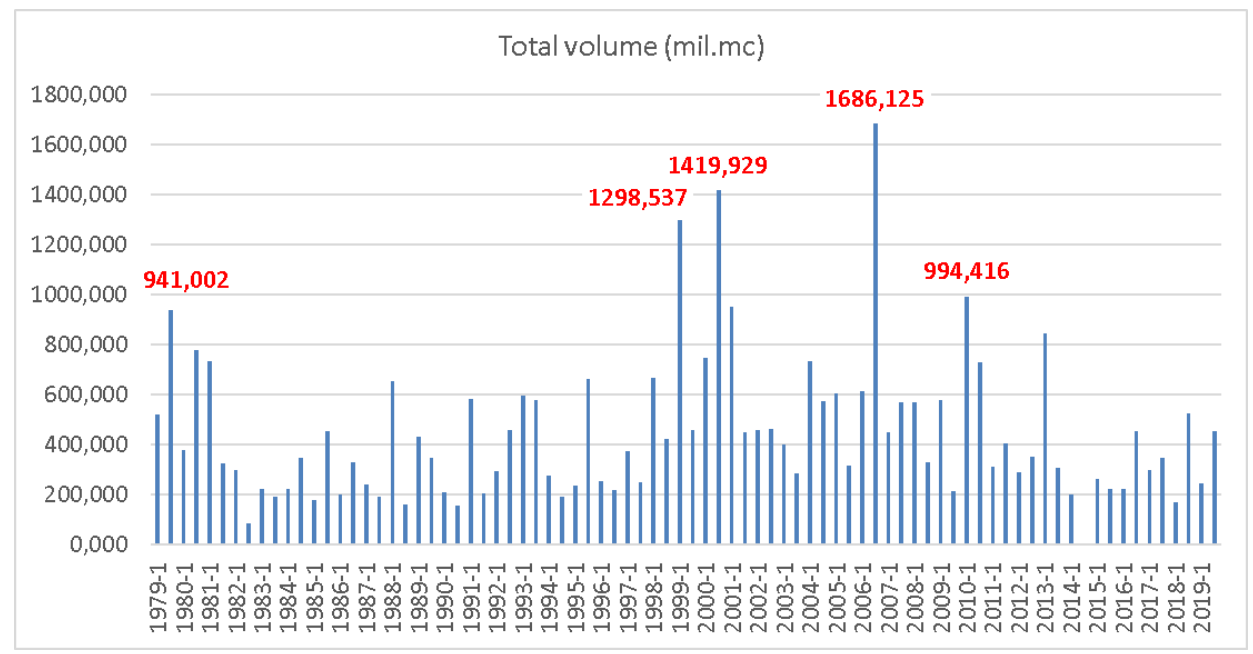

Fig. 6. The total volume values observed during flood events (1979-2019)

An important role in flood mitigation is played by the complex hydro-technical facilities developed in the Someșul Mic upper basin which can now minimized almost every flood event formed upstream of Cluj-Napoca.

However, the peak discharges reached during these events at Satu Mare station, overpass frequently the threshold safety levels, which can lead to a certain risk, for the population and properties situated on the river banks.

\section{REFERENCES}

1. Arghiuş V. I., (2008), Studiul viiturilor de pe cursurile de apă din estul Munţilor Apuseni şi riscurile asociate, Editura Casa Cărţii de Ştiinţă, Cluj Napoca.

2. Bătinaş, R., Sorocovschi, V., Şerban, Gh., (2002), Fenomene hidrologice de risc induse de viituri în bazinul inferior al Arieşului, Seminarul Geografic Dimitrie Cantemir, Iaşi.

3. Bătinaș, R., Șerban, Gh., Nacu S., (2014) The historic flood on the river Lăpuş; (Transylvania, Romania) - genesis, the features and effects in the territory, Proceedings of 14th GeoConference on Water Resources, Forest, Marine and Ocean Ecosystems, Editura SGEM, Albena, Bulgaria.

4. Chendeș V., Corbus, C., Petreș Nicoleta, (2015), Characteristics of April 2005 flood event and affected areas in the Timis-Bega Plain (Romania) analysed by hydrologic, hydraulic and GIS methods, Proceedings of 15th GeoConference on Hydrology and Water Resources, Editura SGEM, Albena, Bulgaria. 
5. Mustățea, A., (2005) Viituri excepționale pe teritoriul României, Editura Onesta 94, București

6. Șerban Gh., Sabău D., Bătinaș, R., Brețcan, P., Ignat, Elena, Nacu,S., (2020), Water Resources from Romanian Upper Tisa Basin, chapter in book: Water Resources Management in Romania, Springer.

7. *** Cavis software - developed by Ciprian Corbuş, INHGA, Bucureşti.

8. *** Hydrological data recorded at Satu Mare hydrometric station, RWNA Romanian Waters National Administration, Someş-Tisa Branch, Satu Mare hydrological station $1974-2019$. 